\title{
Corporate Social Responsibility in Islamic and Conventional View: A Theoretical Approach
}

\section{Nur Faliza, Muhammad Adam, Hasan Basri, and M. Shabri Abd. Madjid}

University of Syiah Kuala, Aceh, Indonesia

\section{Abstract}

This article is a literature study on CSR in conventional and Islamic banks, which is the result of research in the field of strategic management. CSR is not a foreign subject for the organization, it is not only related to the law but more than that it is part of the company's ethics in operation. Islamic banking and conventional banking is inseparable from morals and ethics whose activities relate to the public. CSR has become important for Islamic and conventional banking, but in reality, these two banks differ both in philosophy and in operation. Islamic banking is more emphasis on social orientation without neglecting profit, a banking system that is run based on sharia law to prosper

Corresponding Author: Nur Faliza

nurfaliza@unimal.ac.id

Received: 18 January 2019

Accepted: 24 March 2019

Published: 31 March 2019

Publishing services provided by Knowledge E

(c) Nur Faliza et al. This article is distributed under the terms of the Creative Commons

Attribution License, which permits unrestricted use and redistribution provided that the original author and source are credited.

Selection and Peer-review under the responsibility of the First ELEHIC Conference Committee.

\section{G OPEN ACCESS} society and reach Falah. While conventional banks are more profit-oriented, CSR in conventional banking emphasizes improving financial performance. Theoretically, CSR in Western concepts can be applied in Islamic organizations, but the content remains different.

Keywords: CSR, Islamic Banking, Conventional banking, Syariah

\section{Introduction}

Corporate social responsibility or better known as CSR is synonymous with the ethics and morale of the organization, there is currently no company unrelated to CSR and the whole world recognizes it [1]. There have been many studies on CSR activities related to CSR activities that impact on company performance [2]. CSR has become the most important part of the banking program to get solutions in social issues and community welfare [3]. For the Bank, CSR is a long-term investment, one of its objectives is to improve the banking reputation in the eyes of the public $[4,5]$ and improve the welfare of society [6].

CSR is a multidimensional construct and research has proven CSR with a more appropriate stakeholder theory approach for the banking industry [7]. CSR is a strategy for banks to achieve long-term financial performance but also for stakeholders [5]. Stakeholder theory has become the basis for the concept of CSR West and has become a 
major theme in current discussions on CSR, although some studies have sought to build CSR in Islamic concepts [8]. The phenomenon of CSR in the West's view is often studied both empirically and theoretically [9]. There are still limited studies that are investigating CSR in Islamic banking with the context of Islamic view. This study seeks to fill the gap and will be a reference for researchers to investigate the differences in CSR in both banks.

\section{CSR Conceptualization}

CSR is a relatively new concept in management science [10] and there is no standard definition of corporate social responsibility Dahlsruld 2008; [11, 12], each researcher defines corporate social responsibility according to their needs, the definition of corporate social responsibility is an ongoing agenda today [13-15]. Although we all know that [16, 17] has introduced corporate social responsibility in four categories: economic, ethical, legal and discretionary, and currently, there have been many studies examining corporate social responsibility by using that theory [18].

Various definitions have been put forward to describe corporate social responsibility, such as the Commission of the European Communities / CEC [19] in its green paper defines CSR as a corporate concept integrated with social and environmental concerns in the operation as well as corporate interaction with stakeholders based on volunteer. For companies considering CSR based on the definition of the CEC, which means that company success is measured by a triple bottom line approach that is a combination of economic, social and environmental aspects [20].

CSR is a sustainable economic and business activity and more than a legal requirement to protect the well-being of employees, communities and the environment [21, 22]. CSR includes an environment sustainability and human sustainability component that creates workplace justice, development and workplace health, and adds value to other stakeholders including suppliers, customers and other community members [20].

\subsection{Islamic perspective on CSR}

In Islam, CSR is a must (mandatory) and has been embedded in fundamental Islamic teachings [2, 9] and sharia is fundamental to understanding CSR in Islam [9, 23]. Islam has made various rules in human life, which are the foundations in Islam that can not change, such as aqidah (beliefs and beliefs), worship and morals (morality and ethics) $[9,24]$. Islam provides complete guidance for every stage of human life that is religion, 
business and social justice. Every Muslim must play an active role in his environment in order to develop and improve spirituality and social justice [6]. In Islam the economic activities of the organization are not only to achieve internal profits but also the common welfare or in other words social and economic justice [25]. In the Islamic perspective socio-economic activities should be based on the principle of justice [26, 27].

CSR in Islam has been linked with the maslahah namely the common welfare to achieve falah [23]. CSR is a concept rooted in ethical values [8], which is very inherent with Islamic culture [9]. CSR in the view of Islam is a holistic concept and integrated with sharia law based on Al-quran and sunnah [6, 9, 28], which contains strong ethics and morals, and become guidelines for the company to carry out its business activities that can not be separated from corporate social responsibility [9].

In the Islamic perspective, CSR has a broad meaning that under any circumstances must lead to the value of truth (taqwa). One's ability to develop and manage the world according to the principles and values of sharia is a person of truth and every employee in the company must play its role and responsibility as a servant of God [24]. Furthermore [24] points out that there are four principles that become the main foundation of Islamic CSR namely:

\subsubsection{Unity}

Allah is One and truly the One who created the earth and the universe, this is the main principle in Islam. The Qur'an (57: 5) states that Allah is the last owner of everything on earth and in the universe and ultimately man is accountable to Allah (Qur'an, 2:28). That is, all economic activities (trade / commerce) must be in accordance with the principles and values of sharia, because all will be accountable to Allah Subhanahuwataala.

\subsubsection{Vigerency and trusteeship}

Humans are khalifah or representative of Allah on the earth, As a caliph or a leader in the organization, they have a greater responsibility to utilize the things that belong to Allah to utilize all the facilities provided by Allah for their best ability in creating maximum added value for the organization itself and for the entire community as well. 


\subsubsection{Justice and equalibrium}

In Islam, humans are caliphs (leaders). To fulfill their role as representatives, they must cooperate and support each other, be honest, sincere, keep promises and honest in their business affairs. The Balance must be done by treating people fairly that is fair in the distribution of wages without discrimination. By means of the principles of justice and balance, organizations can create a harmonious life in all societies

\subsubsection{Rights and responsibilities}

Every action taken must be accounted for by each individual. Allah has given humans the intellectual ability to be able to distinguish between what is right and what is wrong so that they can direct their own lives (having freedom or free rights). Of course, this right must be in accordance with sharia law and protect common interests and welfare.

\subsection{CSR in conventional banking}

Banking is a profit-oriented institution, and public trust has underpinned their banking activities. The high expectation of society to the banks influenced him to contribute in the prosperity of society [29]. Therefore, banking is urgently needed to engage in CSR [30], and based on research conducted by [31] revealed that financial institutions are committed to CSR activities. There are three reasons why the importance of CSR in banking is 1) public view and regulators related to banking CSR activities, 2) the views of bank managers that CSR is one of the approaches used to improve banking reputation in obtaining trust from consumers, 3 ) loans banks are critical to the growth of industries including the unethical industries [30].

Implementation of CSR in conventional banking is inseparable from the triple bottom line concept of economic, social and environmental [5, 29]. There have been many studies conducted on conventional banking related to CSR, which express the interest of banks in solving social and welfare problems and become proactive investors in CSR activities [3]. A number of studies conducted on conventional banking, such as Fatma dan Rahman (2016), use the CSR concept of Carrol [16, 17]. Krodomska, Studied CSR in conventional Poland banking by using the CSR index [29]. Research Wu and Shen on CSR in the banking industry with reference to covering multidimensional of social performance consisting of labor, environment, community, human rights, supply chain management and others [5]. A number of CSR studies on conventional banking 
emphasizes the increasing profit received by firms that are in financial performance such as [4], [32], [29], [5] and [33].

\subsection{CSR in islamic banking}

Islamic banking is a bank that operates based on Islamic law, which must comprehensively understand the objectives of Islamic economics. Islam emphasizes social justice, therefore, Islamic banks are expected to be more socially responsible than conventional banks [34]. In Islamic financial institutions social responsibility is interpreted as ethics and philanthropy [35]. Associated with sharia law, organizations and individuals around the world approve of Islamic financial institutions that are considered more fulfilling ethical and moral aspects $[23,36]$. The principle of Ethics and morality comes from the divine revelation that is eternal and absolute [37]. Therefore, ethics and morals are principles that serve as a better guide for companies to apply simultaneously their business and social responsibility responsibilities [6].

Islamic ethics has various linkages to sharia banking, such as those relating to the welfare of individuals and communities or CSR [38]. CSR in Islamic banking emphasizes ethical values and social responsibility, and is based on the principles of sharia law [28, 39] Sharia law prohibits usury, gharar, destroys the environment and puts more emphasis on moral and ethical behavior $[8,25]$. Zakat, qard al hasan (loan without interest), waqaf, sadaqa (charity) [26], and employees [2, 25, 34] forms or activities of CSR in Islamic banking [25].

\subsubsection{Zakah}

Zakat is the fourth pillar of Islam, which is literally meaningful purification and has been mentioned in many verses in Al Quran and Hadith [27]. Ibn Faris as quoted by [40] defines Zakat as growth, increase, purity and cleaness. The word zakah has been mentioned 30 times in the Qur'an [40] such as in Surat At-Tawbah Verse 103, Allah says "Take zakat from some of their property, by charity you cleanse and purify them and pray for them. Verily, your prayer is a serenity for them. and Allâh is All-Knowing All-Knowing ". Then the letter of Al-Maidah verse

55, Allah says "Verily your helper is Allah, His Messenger, and those who believe, who establish prayers and pay zakat, while they submit to Allah". The Qur'an is very clear about the obligatory obligations of God's servants to clean up their property and 
over-love of property. With zakat will be able to cultivate all the good in human beings and increase their property. Qard al hasan

Commitment to provide loans or qard al hasan, is part of CSR activities in sharia banking [25]. Qard al hasan is a loan with no interest and no deductions to the money [41]. Qard al hasan is a type of unpaid loan granted to people in need during certain periods without interest or profit payments. The borrower qard al hasan is only required to pay off the principal amount of the loan [25]. Al quran and sunnah be the legal basis in running qard al hasan. This can be seen in the hadith of Prophet Rasulullah Sallallahualaihi wassalam which reads: "Whoever reduces the difficulties of a Muslim in this life, Allah will lighten one of his troubles on the Day of Judgment, and whoever hinders the financial difficulties of a Muslim, Allah will alleviate his difficulties in this life and the hereafter, and God always helps the faithful as long as he helps his brother" [42].

\subsubsection{Waqaf}

Waqaf is a donation of charity that cannot be revoked under Islamic law, waqaf types of which are buildings, land or other assets whose purpose is for religion or charity without the intention to reclaim the asset. Donated assets are held by charity trust, known as waqif, donor. The meaning of waqaf in terminology or the terms conveyed by Hassan 1984 as cited by [43] is aconfinement and a prohibition or cause something to stop or stand still. Further, Hasan interpreted waqaf ie "stand still, silently do not let go". Referring to [43] literationally waqaf is an asset-ownership aimed at a particular charity determined by the waqif by giving asset use to the designated beneficiaries. Waqaf is a voluntary donation to provide assets to a designated party without the will to take back the asset. Waqf is not only in the form of land and buildings but also can be a liquit assets like money [43]. Waqaf is given for the benefit and welfare of the community or social services [40].

\subsubsection{Sadaqah}

Sadaqah/Alms based on literacy is the giving of a Muslim to others voluntarily and sincerely without being limited by time and quantity. The basic concept of Sadaqa (voluntary almsgiving / charity) is to give and help without expecting reward, sincerity for Allah [44]. Islam advocates his people to give charity, as in the words of Allah SWT below: "Allah destroys usury and fosters alms. And Allah dislikes everyone who abides in unbelief and always sins (Al-Baqarah: 276) ". Sadaqah is a charity that will keep flowing 
reward, even though the charity is gone. Rasulullah SAW, said: "When the son of Adam dies then is cut off from him all good except the three things that is alms jariyah, useful knowledge and pious son who pray for him" [42].

\subsubsection{Employee}

Employees are a very important human resource in the banking industry, which is an intangible asset of banking in addition to financial assets [29]. The organization is responsible for ensuring that its employees are paid for a fair wage, working in accordance with their obligations and responsibilities. Have the opportunity to fulfill their spiritual obligations and Islam is giving priority to equal opportunity between fellow human beings. Banking sector is a service sector with a very competitive level of competition, the bank must have value that is able to attract the public to become a customer, business partner or partner with the bank. To that end, banks must have competent human resources that have knowledge, expertize and understanding of sharia banking which is one of the key to the success of sharia banking. therefore the need for corporate social responsibilities for employees is the training and development of employees, promotions and rewards [34]. It is important for banks to be able to manage their human resources in accordance with sharia banking policy.

\subsubsection{Environment}

Islam forbids to destroy or damage the physical environment that is considered harmful to individuals or society. Therefore, sharia banks are not expected to finance activities that cause harm to the environment. Sharia banks must provide funds in environmental conservation projects. While sharia banking is unlikely to cause direct damage to the environment, such as the nuclear industry, under the CSR policy, sharia bank users will need to ensure that the activities of these banks have affected the welfare of the community [34].

In its activities Islamic banks cannot be separated from its responsibility to the external environment. Through its financing program, Islamic banks must be able to assess projects to be funded, by not financing projects that cause environmental damage. Improve environmental protection and promote energy-efficient projects and be active in donating and active in activities aimed at protecting the environment [34]. 


\subsection{CSR: Islamic and conventional world view}

CSR is a long-known concept that deals with corporate responsibility for the internal environment and the external environment. There have been many western concepts explaining about CSR in various industries, such as services, manufacturing, and banking. Islamic and conventional banking is an institution that is synonymous with ethics (known as cooperative bank, charity bank) has unequal values and aspirations. They have operate by building different philosophies and environments. Based on Western literature CSR emphasizes on four dimensions of environment, human resources, philanthropy and human rights [25]. Below is a figure of CSR practice that refers to some Western theories that have conceptualization by Dusuki [25].

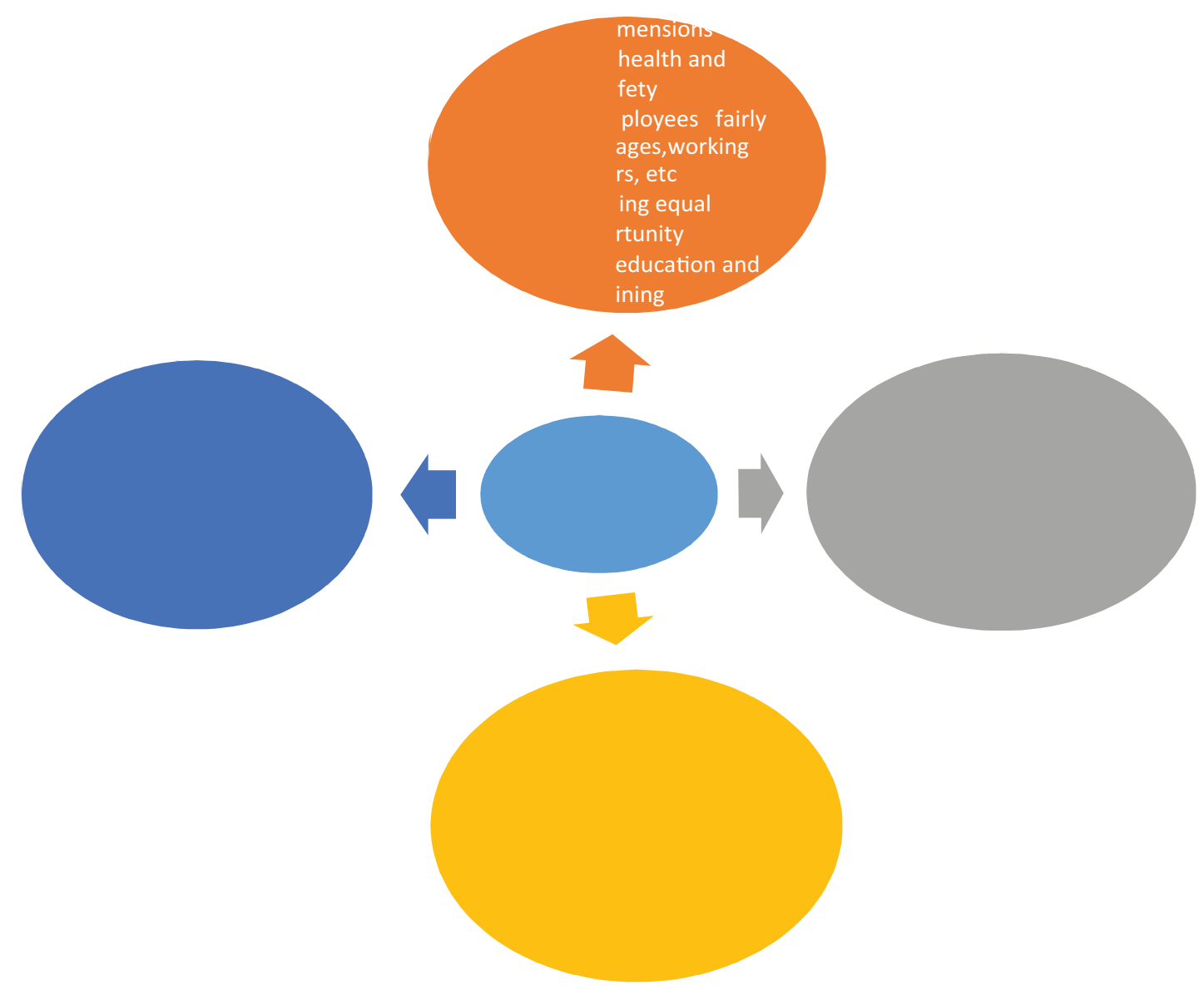

Figure 1: CSR practice in West concepts.

The dimensions of corporate social responsibility as long as in accordance with the spirit and teachings of Islam, can be applied to Islamic banking. The following table below refers to [25] presenting some verses of the Al-Quran and Hadith based on the CSR dimension in the picture above. 
TABLE 1: Islamic perspective on CSR practice.

Western Guidelines to CSR Practice

1. Human Rights

Dimension

2. Human Resource

Dimension

3. Environmental

Dimension

4. Philanthropic

Dimension

\section{Conclusions}

Fundamentally Islamic banking and conventional banking are different, not only from its business practices but also all the values that serve as guidelines for the operationalization of Islamic banking[23]. Religious values are more emphasized in Islamic banking than conventional banking, Islamic teachings underlie the activities of CSR and even the whole of Islamic banking activities. In conventional banking CSR is based only on theories developed by Western scholars, profit oriented becomes the main focus in a. Allah said, "I have made oppression unlawful for my self and for you, so do not commit oppression against one another" Sahih Muslim, vol.3, hadith no. 6254

b. Help your brother whether he is the oppressor or the oppressed..If he is an oppressor, prevent him from doing it, for that will be helping him, and if he is oppressed he should be helped (against the oppressor)" Sahih Muslim, vol.3, hadith no.6246

a. "Your employees are your brethren over whom Allah has given you authority.

So if one of you has his brother under his control, you should feed him with the like of what you eat and clothe him with the like of what you wear. You should not overburden him with the like of what you aet and clothe him with the like what you wear. You should not overburden him with what he cannnot bear, and if you do so, helphim in his job". Sahih Muslim vol.3, hadith no. 4093

b. Allah Subhanau Wata'ala says, "I will be an opponent to three person on the Day of judgment: one who make a covenant in My name but proves treacherous;one who sells a free person (as a slave) and consumes the price; and one who employs a labourer and receives his full labour but does not pay his wages". Sahih Bukhari, vol.3, hadith no. 2.

a. And when he turns away, he strives throughout the land to cause destruction therein and destroy crops and animals. And Allah does not like mischievous acts" (Al-Qur'an 2:205).

b. And do no mischief on the earth after it has been set in order, but call on Him with fear and aspiration. Indeed the mercy of Allah is near to the doers of good" (Al-Qur'an 7:56).

a. "And fear Allah as much as you can, listen and obey; and spend in charity for the benefit of your own souls. And those saved from the covetousness of their own souls, they are the ones who achieve prosperity" (Al-Quran 64:16).

b. "Every Muslim must pay sadaqah (charity)." A companion asked, "What about someone who has nothing to give?" The Prophet replied, "Then let him do something with his two hands and benefit himself. That will be charity."

A companion asked, "But what if he cannot do that?" The Prophet replied, "Then he can help someone who is needy." They asked, "What if he cannot do even that?" The Prophet replied, "Then he should enjoin the doing of good." Still again they asked, "But what if he cannot do that?" The Prophet replied, "Then he should refrain from evil, for that is a form of charity." Al-Bukhari's al-Adab al-Mufrad, hadith no. 225 
conventional banking. Contrast with Islamic banking, there is a balance between profit and social welfare for society. CSR activities in Islamic banking are expected in accordance with ethics based on Islamic principles, by conducting legitimate transactions, prohibiting usury and speculation in business transactions [42].

\section{References}

[1] Bakar, F. A., and Yusof, M. A. M. (2015). Islamic concept of corporate social responsibility (CSR) from the perspective of CSR players at Bank Islam Malaysia Berhad. International Conference on Acounting Studies (ICAS).

[2] Jusoh, W. noor H. W., Ibrahim, U., and Mohd.Napiah, M. D. (2015). An Islamic Perspective on Corporate Social Responsibility of Islamic Banks. Mediterranean Journal of Social Sciences, 6(2), 308-315.

[3] Fatma, Mobin.,and Rahman, Zillur. (2015). Consumer perspective on CSR literature review and future research agenda. Management Research Review, 38(2), 195-216.

[4] Bihari, S. C., and Pradhan, S. (2011). CSR and Performance: The Story of Banks in India. Journal of Transnational Management, 16(1), 20-35.

[5] Wu, M., and Shen, C. (2013). Corporate social responsibility in the banking industry: Motives and financial performance. JOURNAL OF BANKING FINANCE, 37(9), 35293547.

[6] Khursyid, M.A., Al-Ali, Abdulrahman., Soliman, A. A., \& Amin, S. M. (2014). Developing an Islamic corporate social responsibility model (ICSR). Competitive Review, 24(4), $258-274$.

[7] Pérez, A., and Rodríguez del Bosque, I. (2014). Customer CSR expectations in the banking industry. International Journal of Bank Marketing, 32(3), 223-244

[8] Bella, V. Di, and Al-Fayoumi, N. (2016). Perception of Stakeholders on Corporate Social Responsibility of Islamic Banks in Jordan. EuroMed Journal of Business, 11(1), $1-46$.

[9] Dusuki, A. W. (2008). What Does Islam Say about Corporate Social Responsibility? Review of Islamic Economics, 12(1), 5-28.

[10] Skudiene, V., and Auruskeviciene, V. (2012). The contribution of corporate social responsibility to internal employee motivation. Baltic Journal of Management, $7(1)$, 49-67.

[11] Dahlsrud, Alexander (2008).'How Corporate Social Responsibility is Defined: An Analysis of 37 Definitions. Corporate Social Responsibility and Environmental management, pp. 1-13. 
[12] McWilliams, Abagail, Siegel, Donal S and Wright, Patrick M (2006). Corporate Social responsibility: Strategic Implication. Journal of management studi, vol. 43 No. 1 pg $1-18$

[13] Sheehy, B. (2015). Defining CSR: Problems and Solutions. Journal of Business Ethics, 131(3), 625-648.

[14] Taneja, S. S. (2011). Researches in Corporate Social Responsibility: A Review of Shifting Focus, Paradigms, and Methodologies, 343-364.

[15] Sobczak, A., and Havard, C. (2014). Stakeholders' Influence on French Unions' CSR Strategies. Journal of Business Ethics, 311-324.

[16] Carroll, A. B. (1979). a Three-Dimensional Conceptual Model of Corporate Social Performance. Academy of Management Review, 4(4), 497-504.

[17] Carroll, a. B. (1999). Corporate Social Responsibility: Evolution of a Definitional Construct. Business \& Society, 38(3), 268-295.

[18] Carroll, A. B., and Shabana, K. M. (2010). The business case for corporate social responsibility: A review of concepts, research and practice. International Journal of Management Reviews, 12(1), 85-105.

[19] Commission of the European Communities (2001). Green Paper: Promoting a European Framework for corporate Social Responsibility. europa.eu/rapid/pressrelease_DOC-01-9_en.pdf

[20] Farook, S. (2007). On Corporate Social responsibility of Islamic Financial Institution. Islamic Studies, 15(1), 32-46.

[21] Heslin, P. A., and Ochoa, J. D. (2008). Understanding and developing strategic corporate social responsibility. Organizational Dynamics, 37(2), 125-144.

[22] Barrena-martinez, J., Romero-fernandez, P. M., and Romero-fernández, P. M. (2011). Research proposal on the relationship between corporate social responsibility and strategic human resource management Macarena López-Fernández and, (November).

[23] Dusuki, A.W (2008). Understanding the objectives of Islamic banking: a survey of stakeholders' perspectives. International Journal of Islamic and Middle Eastern Finance and Management, 1(2), 132-148

[24] Elasrag, H. (2015). Corporate Social Responsibility: An Islamic Perspective. Online at https://mpra.ub.uni-muenchen.de/67537/MPRA Paper No. 67537,

[25] Dusuki, A. W. (2011). Ethical and Social Responsibility Models for Islamic Finance. ISRA Research Paper, (28), 1-38. 
[26] Farook,S., Hassan, M. K., and Roman, L. (2011). Determinants of corporate social responsibility disclosure: the case of Islamic banks. Journal of Islamic Accounting and Business Research, 2(2), 114-141.

[27] Aribi, Z. A., and Gao, S. S. (2011). Narrative disclosure of corporate social responsibility in Islamic financial institutions. Managerial Auditing Journal, 27(2), 199-222.

[28] Jamali, Dima and Mishak, Ramez (2007). Corporate Social Responsibility (CSR):Theory and Practice in a Developing Country Context. Journal of Business Ethics pg 243-262.

[29] Krasodomska, J. (2015). CSR disclosures in the banking industry. Empirical evidence from Poland. Social Responsibility Journal, 11(3), 406-423.

[30] Shen, C., Wu, M., Chen, T., and Fang, H. (2016). To engage or not to engage in corporate social responsibility: Empirical evidence from global banking sector. Economic Modelling, 55, 207-225. http://doi.org/10.1016/j.econmod.2016.02.007

[31] Jain, A. K. (2014). Volunteerism and organisational culture Volunteerism and organisational culture Relationship to organizational commitment and citizenship behaviors in India Relationship to organizational commitment and citizenship behaviors in India. Cross Cultural Management: An International Journal, 22(1), 116-144.

[32] Esteban-sanchez, P., Cuesta-gonzalez, M. De, and Paredes-gazquez, J. D. (2017). Corporate social performance and its relation with corporate fi nancial performance: International evidence in the banking industry. Journal of Cleaner Production, 162, 1102-1110.

[33] Weber, O. (2017). Corporate sustainability and financial performance of Chinese banks. Sustainability Accounting, Management and Policy Journal, 8(3), 358-385.

[34] Hassan, A., and Harahap, S. S. (2010). Exploring corporate social responsibility disclosure: the case of Islamic banks. International Journal of Is/amic and Middle Eastern Finance and Management, 3(3), 203-227.

[35] Sairally, S.B. (2013). Evaluating the corporate social performance of Islamic financial institutions: an empirical study. International Journal of Islamic and Middle Eastern Finance and Management, 6(3), 238-260.

[36] Khan, M. M., and Bhatti, M. I. (2008). Development in Islamic banking: a financial riskallocation approach. The Journal of Risk Finance, 9(1), 40-51.

[37] Ahmad, Khaliq. (2003). Management Modelling from Islamic Perspective: Some Reflections. 'Ulum Islamiyyah.

[38] Mostafa, R. B., and ElSahn, F. (2016). Exploring the mechanism of consumer responses to CSR activities of Islamic banks The mediating role of Islamic ethics fit. International Journal of Bank Marketing, 34(6), 940-962. 
[39] Aribi, Z. A., and Arun, T. (2015). Corporate Social Responsibility and Islamic Financial Institutions (IFIs): Management Perceptions from IFIs in Bahrain. Journal of Business Ethics, 129(4), 785-794.

[40] Ahmed. (2004). Role of Zakah and Awqaf in Poverty Alleviation. Occasional Paper, Islamic Research and Training Institute. Islamic Departement Bank Group, Jeddah.

[41] Rahman, Y. A. (2014). The Art of RF Islamic Banking (Riba-Free) and Finance. Second Edition. John Wiley \& Sons, Inc.

[42] Muslim, H.N. (1955). Sahih Muslim, Ed. Muhammad Fu'ad 'AbdulBaqi. Dar Ihya' alKutub al-'Arabiyyah, pp: 1031.

[43] Nahar, H. S., and Yaacob, H. (2011). Accountability in the sacred context The case of management, accounting. Journal of Islamic Accounting and Business Research, 2(2), 87-113.

[44] Bensaid, B. (2017). Ethico-Spiritual Dimensions of Charity: An Islamic Perspective. Middle-East Journal of Scientific Research, 